\title{
Obituaries
}

\section{In memory of Bill Brugger (1941-1999)}

\author{
Andrew Watson
}

Bill Brugger's death in Adelaide on 23 August came after a number of years of poor health and a short, but intense, fight against cancer. His many friends in Chinese studies and the generations of students he taught were much distressed by this premature departure of a significant contributor to the study of contemporary China. Many of us will recall, with deep pleasure, long discussions of the nature of political change in China and of political theory, in which Bill's engaging manner and concentration on exploring the theoretical meaning of events stimulated us to seek our own new perspectives. Such moments inevitably remain linked in memory with the soft bubbling of his ever-present pipe. Bill will be remembered as an engaged and productive scholar, as a fine teacher, as a generous intellectual who engaged in debate without spite, and as a good friend. Indeed, the warmth of feeling towards him was evident in the last few weeks of his life, when many of his colleagues and former students made journeys from distant parts of the world to say farewell. Bill was philosophical in the face of his illness, and these visits were another opportunity for him to reflect on China and political theory. He will be keenly missed.

Bill's engagement with Chinese Studies began in 1960, when he enrolled in the Modern Chinese degree at SOAS. At that time, few universities in Britain taught Chinese and few students chose the option. The field was open for creative people, and Bill is one of those who left his mark. During his undergraduate days at SOAS, Bill developed the broad sinological foundation that has been a feature of British scholars working on China. He also demonstrated the qualities that became characteristic of his scholarly life and shaped the way he subsequently organized his teaching and research. He was intensely methodical and systematic. I recall how, in 1964, as finals approached, he organized groups of classmates to work as teams, focusing on different periods of Chinese history and sharing the fruits of their work. I suspect a number of us owed what success we had in the final paper to this effort. This approach also underlined the extent to which Bill was committed to working with others, exchanging ideas and enjoying the sparks that could come from discussion and debate. This characteristic was most apparent in the 1970s and 1980s, when he organized and edited a series of books on political change in China that were the product of regular workshops and discussion groups.

Another feature of Bill's early days at SOAS was his commitment to social engagement. He ran for various offices in the student union and, probably not a widely known achievement, starred in a spoof film loosely based on a George Simenon novel. His experience later in China in- 
tensified his sense of commitment to the social role of scholarship and, during the 1960s and 1970s, when student activism flared in Britain and Australia, Bill was firmly on the side of an open and participatory structure for academic life. Bill was always conscious of the political significance of events in China and of the political context for Chinese studies.

On graduating from SOAS, Bill became one of the group of young British scholars that was able to spend time in China before and during the Cultural Revolution. China had, at that time, just changed to English as the first foreign language and was seeking English language teachers. This gave him the rare opportunity to engage with a society previously studied at a distance and in the abstract. It was also a society undergoing intense and consciously debated change. In retrospect, this was a key formative period for him. It not only brought the language alive and enabled him to come to grips with China's social reality, but also stimulated an abiding interest in political theory and the relationship between theory and social practice. Bill's commitment to a scholarly life devoted to exploring China's reality through the lens of political theory became a fundamental driving force of the rest of his life.

On returning to Britain in 1966, Bill embarked on a programme of study that resulted in his Ph.D. thesis in 1972 and led to the publication of Democracy and Organisation in the Chinese Industrial Enterprise 1948-53 (1975). This book remains one of the most solid studies of the period and of the socialist transition in Chinese industry. Its meticulous analysis of a complex and detailed process was based on extensive documentary research and had a clear theoretical focus that demonstrated Bill's lifelong commitment to linking the particular to the theoretical. The book underlined Bill's interest in socialist theory and in studying China as a means to elucidate socialist perspectives on political thought. During this time, Bill also became the Materials Officer at the Contemporary China Institute at SOAS and worked to develop its basic collection of primary materials. Bill thus made a significant contribution to the Institute that served for many years as one of the world's major centres for research on contemporary China.

In 1972, Bill moved to the Flinders University of South Australia as a lecturer in politics. He rose to senior lecturer (1976), reader (1978) and professor (1980). He served as head of department throughout the 1980s and was a senior figure on many university committees. His rapid promotion reflected his scholarly output, his organizational abilities and the trust that he enjoyed among his colleagues. He remained a member of the Politics Department at Flinders until his death.

The combination of strong empirical foundations in documentary sources and a guiding focus on socialist theoretical issues became the hallmark of the series of political studies of contemporary China which Bill wrote and edited in the years after completing his thesis. A number of these publications also involved work with his growing list of successful postgraduate students (he supervised 14 theses in total), and it was characteristic of the man to generate opportunities for his students to 
publish their work. It is not surprising, therefore, that they have always shown him great loyalty. His corpus of work included five individual books, four jointly written books, three edited volumes and numerous chapters and journal articles. His students have become lecturers and professors in a number of universities in Australia and in Hong Kong.

As time passed, Bill became increasingly engaged with the broad range of political theory. His intellectual interests took him well beyond China. Indeed, in recent years, as the reassessment of political change and of the Cultural Revolution in China proceeded, Bill not only contributed to that discussion but also developed a growing interest in the impact of postmodern thought. He published on an extensive variety of issues including classic British and European liberalism, socialist theory, technocracy and Australian politics. His last book, Republican Theory in Political Thought, engaged with the issue of the moment in Australia. He was also a frequent contributor to radio and newspaper commentary. His capacity to sustain this breadth to his scholarship was a testimony to the strength of his intellect.

For those who knew him, his sense of intellectual engagement, the breadth of his work and his capacity to retain a focus on the theoretical heart of scholarship will remain at the core of our memories. As will his warmth, generosity and kindness.

\section{Jacques Guillermaz (1911-1998)}

\section{Claude Aubert}

On 2 February 1998, Jacques Guillermaz died at 87 after a long and dignified fight against illness. He was not only the founder of French studies on Contemporary China, but one of the last first hand witnesses of more than fifty years of recent Chinese history.

"The most beautiful journey is not worth a modest come back." This quotation, from a poem by $\mathrm{Gao} \mathrm{Qi}$, found in his autobiography Une Vie pour la Chine, Mémoires, 1937-1989 (1989), may summarize the feelings of a man who personally paid a heavy price for having travelled so deeply into the turmoil of China's recent past: he gave that country the best part of his youth. Indeed, the last twenty years of his life, after he had retired to a small village in the Savoie near Grenoble, may have been the happiest of his life. The love and care of his third wife, as well as the peace of the countryside, gave him the serenity to look back at the hopes and the disillusionment he experienced in the face of so many lost opportunities, to wish the best for a country he admired more for its civilization and its people than for its politics.

But what a journey! Born the same year the Manchu dynasty collapsed, Guillermaz arrived in Beijing in May 1937, two months before the city 